\title{
PROFIL BERPIKIR LATERAL SISWA DALAM PEMECAHAN MASALAH GEOMETRI DITINJAU DARI TAHAP BERPIKIR VAN HIELE
}

\author{
Restu Ria Wantika \\ Pendidikan Matematika , Fakultas Keguruan dan Ilmu Pendidikan, \\ Universitas PGRI Adi Buana Surabaya \\ restu@unipasby.ac.id \\ Eka Susilowati \\ Pendidikan Matematika , Fakultas Keguruan dan Ilmu Pendidikan, \\ Universitas PGRI Adi Buana Surabaya \\ eka250@gmail.com
}

\begin{abstract}
Abstrak
Tujuan penelitian ini adalah untuk mendeskripsikan berpikir lateral siswa dalam pemecahan masalah geometri ditinjau tahap berpikir van Hiele. Manusia memiliki pemikiran pada sesuatu hal khususnya matematika menekankan pada pemikiran logis, sehingga salah satu cara berpikir yang cocok digunakan adalah berpikir lateral. Salah satu hal yang dapat melatih berpikir lateral adalah dengan menyelesaikan masalah. Geometri merupakan pokok bahasan matematika yang bisa mendukung untuk mengetahui cara berpikir lateral siswa dikarenakan melatih siswa untuk berpikir kreatif untuk mencari alternatif-alternatif pilihan untuk memecahkan masalah. Jenis penelitian ini adalah penelitian kualitatif. Subjek penelitian adalah tiga siswa kelas VIII SMP. Subjek dipilih berdasarkan hasil tes VGHT. Metode pengumpulan data yang digunakan adalah observasi selama pembelajaran, tes dan wawancara mendalam. Instrumen penelitian adalah tes diagnostik dan pedoman wawancara. Analisis data dalam penelitian ini adalah analisis deskriptif kualitatif. Data yang dianalisis adalah data hasil observasi selama pembelajaran, hasil tes dan hasil wawancara mendalam yang digunakan untuk mendeskripsikan proses berpikir lateral siswa dalam pemecahan masalah geometri.
\end{abstract}

Kata Kunci: Berpikir lateral, Geometri, Pemecahan Masalah, Tahap berpikir Van Hiele

\begin{abstract}
The purpose of this study was to describe the lateral thinking of students in solving geometry problems reviewed by the van Hiele thinking stage. Humans have thoughts on things, especially mathematics emphasizing logical thinking, so one of the most suitable ways of thinking is lateral thinking. One of the things that can train lateral thinking is to solve problems. Geometry is a subject of mathematics that can support to know the lateral thinking of students because it trains students to think creatively
\end{abstract}


to find alternative options to solve problems. This type of research is qualitative research. The research subjects were three junior high school students in grade VIII. Subjects were selected based on VGHT test results. Data collection methods used are observation during learning, tests and indepth interviews. Research instruments are diagnostic tests and interview guidelines. Data analysis in this study is qualitative descriptive analysis. The data analyzed were observation data during learning, test results and the results of in-depth interviews which were used to describe the students lateral thinking process in geometry problem solving

Keywords: Lateral thinking, Geometry, Problem Solving, Van Hiele thinking stages

\section{PENDAHULUAN}

Seiring berkembangnya ilmu pengetahuan dan teknologi, kemudahan untuk mengakses informasi dari berbagai penjuru dunia juga semakin meningkat. Oleh karena itu, siswa perlu memiliki kemampuan untuk memilih dan mengolah berbagai informasi untuk dapat tetap bertahan dalam keadaan yang dinamis dan penuh persaingan. Kemampuan untuk memilih dan mengolah informasi membutuhkan pemikiran kritis, sistematis, dan logis. Cara berpikir seeperti itu dapat dilatihkan dan dikembangkan melalui pembelajaran matematika karena matematika memiliki struktur dan keterkaitan antar konsep yang kuat sehingga melatihkan siswa untuk terbiasa berpikir logis.

Matematika merupakan salah satu ilmu pengetahuan yang ikut berkembang. Berkembangnya matematika harus diimbangi dengan berkembangnya kemampuan siswa dalam mempelajari matematika. Dalam pembelajaran matematika, siswa perlu diberi kesempatan mengolah dan mengkonstruksi konsep dan prinsip umum secara mandiri. Hal ini sejalan dengan Freudenthal (1973:15) yang mengemukakan bahwa matematika adalah aktivitas manusia sehingga pembelajaran matematika dipandang sebagai suatu proses bukan barang jadi. Pengetahuan yang baru akan melekat lebih lama apabila siswa dilibatkan secara langsung dalam proses pemahaman dan mengonstruksi sendiri konsep atau pengetahuan tersebut. Matematika merupakan pokok bahasan yang sangat penting dan menarik untuk dikaji lebih dalam karena matematika merupakan mata pelajaran yang dianggap sulit dan momok bagi mereka sehingga matematika hanya sekedar dihafal tetapi tidak dipahami.

Kesulitan mempelajari matematika dapat disebabkan karena objek matematika yang dianggap abstrak dan persepsi atau sugesti siswa yang menganggap matematika adalah materi yang sukar terutama pada materi atau pembelajaran geometri.

Menurut Budiarto (2006) geometri didefinisikan sebagai cabang matematika yang mempelajari tentang titik, garis, bidang dan benda-benda ruang serta sifatsifatnya, ukuran-ukurannya dan hubungan dengan yang lain. Geometri diajarkan di sekolah berguna untuk meningkatkan berpikir logis dan membuat generalisasi secara benar. Seiring berjalannya waktu dan kemajuan teknologi, geometri sudah 
menjadi materi dan pengetahuan yang disusun menarik dan dapat dipikirkan secara logis. Agar dapat memahami aritmatika, aljabar, kalkulus dan lain-lain lebih baik, maka kemampuan konsep geometri oleh siswa harus dikuasai secara mendalam karena disini konsep-konsep geometri berperan sebagai alat.

Berpikir merupakan perkembangan ide dan konsep (Bochenski, dalam Suryasumantri,1995). Saat siswa menghadapi proses kegiatan pembelajaran, siswa melakukan kegiatan berpikir tentang objek yang sudah diberikan (materi pelajaran) dan tugas yang harus siwa lakukan adalah melakukan pengamatan terhadap objek tersebut. Kegiatan berpikir siswa akan terjadi apabila siswa sudah harus menyadari bahwa obyek atau dalam hal ini materi tertentu adalah tidak sederhana, siswa harus mengenal obyek tersebut, membanding-bandingkan apa yang dilihatnya, dan selalu melihat serta menganalisis obyek tersebut dari berbagai sudut pandang yang berbeda. Apabila saat mempelajari materi tertentu melakukan kegiatan menganalisis melalui berbagai sudut pandang siswa, artinya siswa tersebut telah melakukan kegiatan penalaran.

De Bono (1991) menyatakan bahwa dalam proses berpikir, siswa cenderung memberikan respon tunggal tentang halhal yang terkait dengan informasi yang diberikan atau pada saat memecahkan masalah matematika. berpikir tahap demi tahap berdasarkan fakta yang menuju pada satu arah untuk memberikan jawaban atau penarikan kesimpulan yang logis. Hanya sedikit siswa memecahkan masalah matematika dengan berpikir lateral. Berpikir lateral yaitu cara berpikir logis dengan dilakukan tahap demi tahap berdasarkan fakta yang ada, mencari berbagai alternatif pemecahan masalah, dan akhirnya memilih alternatif yang paling mungkin menurut logika normal mereka. Ia juga menjelaskkan bahwa dalam berpikir lateral, ide-ide baru yang muncul tidak terlalu memperhatikan baikburuknya nilai sehingga dapat dengan mudah melompat dari suatu ide ke ide yang lain.

Dalam pembelajaran geometri terdapat teori yang ditemukan oleh Van Hiele untuk mengetahui tahap berpikir siswa yaitu terdapat tahapan berpikir Van Hiele. Tahap berpikir van hiele adalah tahap perkembangan berpikir siswa dalam pembelajaran geometri yang memiliki 5 level yaitu level 0 (Visualization), Level 1 (Analysis), level 2 (Informal Deduction), level 3 (Deduction), dan level 4(Rigor). Level 0 (Visualization), The students see geometric figures as a whole, but they cannot identify the properties of these figures.Level 1 (Analysis). The student can identify the figures and their properties, but they cannot see the interrelationship between different figures, and they also cannot understand definitions, Level 2 (Informal Deduction), students can use definition but they cannot construct a proof, Level 3 (Deduction), students can construct a proof but they cannot understand the rigor of geometrical methods dan Level 4 (Rigor), students understand the geometric methods and generalize the geometric concepts at this level. They are also capable of problem solving.

Pada akhir penelitian ini, diharapkan peneliti mendapatkan gambaran berpikir lateral siswa dalam pemecahan masalah geometri. Adapun materi yang digunakan dalam penelitian ini yaitu bangun datar. Materi ini dipilih karena dapat 
berhubungan dengan teori yang sudah dijelaskan sebelumnya. Disisi lain, pokok bahasan ini juga dapat memunculkan banyak alternatif cara penyelesaian sehingga memungkinkan peneliti untuk mendeskripsikan cara berpikir lateral siswa.

Dengan dasar tersebut di atas, maka peneliti tertarik untuk melakukan penelitian dengan judul "Profil Berpikir Lateral Siswa Dalam Pemecahan Masalah Geometri Ditinjau Dari Tahap Berpikir Van Hiele". Dengan tujuan yang dicapai dalam penelitian ini adalah mendeskripsikan berpikir lateral siswa dalam pemecahan masalah geometri ditinjau dari tahap berpikir Van Hiele.

Adapun metode penelitian yang digunakan antara lain:

\subsection{Jenis Penelitian}

Jenis penelitian ini merupakan penelitian kualitatif. Hal ini dikarenakan dalam penelitian ini, peneliti berusaha mendapatkan data kualitatif yang digunakan untuk mendeskripsikan profil berpikir lateral siswa dalam pemecahan masalah kontekstual.

\subsection{Tempat dan Waktu Penelitian}

Penelitian ini akan dilakukan di SMP Kartika Nasional pada kelas VIII SMP.

\subsection{Subjek Penelitian}

Subjek dalam penelitian ini tiga siswa dari kelas VIII SMP. Adapun prosedur pemilihan subjek penelitian adalah sebagai berikut.

1. Menetapkan kelas penelitian dari kelas VIII SMP.

2. Memilih tiga subjek penelitian.

Subjek penelitian ini dipilih 3 orang siswa SMP kelas VIII di sekolah tersebut. Subjek dipilih berdasarkan hasil Van Hiele Geometry
Test (VHGT), yang berguna untuk menentukan tahapan berpikir siswa. Siswa SMP mempunyai tahap berpikir 0 (recognition) sampai tahap 2 (order) (Burger \& Shaughnessy,1986; van de Walle, 2008). Dengan demikian, subjek penelitian yang dipilih terdiri atas 1 siswa dari masing-masing level. Tes VHGT terdiri atas pertanyaan pilihan ganda (MCQs) dalam lima subtes. Setiap subtes terdiri atas 5 soal berdasarkan pada satu tingkat van Hiele. Sehingga terdapat 15 soal dalam tes untuk menentukan pencapaian peserta didik dari tingkat van Hiele 0,1 , dan 2 pada penelitian ini. Setiap pertanyaan siswa menjawab yang benar sesuai dengan kemampuan tingkat berpikir geometri yang dimiliki. Pada test perkembangan berpikir geometri Van Hiele VHGT setiap level terdiri dari lima pertanyaan dengan kriteria dalam menentukan level berpikir geometri, yaitu (a) Jika siswa dapat menjawab 3-5 pertanyaan dengan benar pada level 0 maka siswa tersebut mencapai tingkat berpikir geometri level 0 ; b) jika siswa dapat menjawab 3-5 pertanyaan dengan benar pada level 1 maka siswa tersebut mencapai tingkat berpikir geometri level 1 danseterusnya; c) jika siswa tidak menjawab dengan benar 3 atau lebih pertanyaan pada level 2, 3 dan 4, maka siswa tersebut mencapai tingkat berpikir geometri level 1. Subjek penelitian dipilih berdasarkan hasil VHGT tersebut dan dari rekomendasi guru. Rekomendasi dari guru kelas diperlukan karena guru kelas lebih mengetahui.

\subsection{Instrumen Penelitian}

Instrumen utama dalam penelitian ini adalah peneliti sendiri, 
karena peneliti merupakan pengumpul data dan menginterpretasi data yang diperoleh selama proses penelitian. Adapun instrumen pendukung yang digunakan dalam penelitian ini yakni berupa wawancara berbasis tes. Oleh karena itu, peneliti menyusun:

1. Tes Pemecahan Masalah (TPM)

$$
\text { Penyusunan }
$$

Tes

Pemecahan Masalah (TPM) diawali dengan mengaji materi matematika yang ditetapkan dalam kurikulum sekolah khususnya pada kelas 8 SMP. Selanjutnya dikaji pemecahan masalah geometri yang berkaitan dengan materi bangun datar. TPM 1 mirip dengan TPM 2, dst. TPM ini dilengkapi dengan petunjuk atau arahan dalam menyelesaikan masalah serta sejumlah butir pertanyaan tertulis.

TPM ini berbentuk soal essay (uraian). Pembuatan soal dalam bentuk uraian bertujuan untuk memudahkan peneliti mengetahui profil berpikir lateral siswa dalam memecahkan masalah geometri. Sebelum soal diberikan kepada subjek, terlebih dahulu soal dikonsultasikan dengan para validator. Soal TPM yang disusun divalidasi oleh tiga orang dosen pendidikan matematika dan dua orang guru matematika SMP.

Validitas yang diukur adalah validitas isi dan validitas konstruk. Validitas isi meninjau tentang kecocokan materi tes yang digunakan dalam mengungkap profil berpikir lateral siswa SMP kelas VIII. Validitas konstruk meninjau tentang ketepatan dalam susunan/konstruksi masalah atau soal seperti butir pertanyaan jelas, dapat dimengerti atau mudah tertangkap maknanya, tidak menimbulkan penafsiran ganda.

Kriteria validitas yang digunakan adalah jika $\geq 80 \%$ validator menyetujui bahwa dari segi kecocokan materi, konstruksi butir-butir pertanyaan serta kejelasan bahasa yang terdapat dalam instrumen ini dapat mengungkap berpikir lateral siswa, maka instrumen ini dikatakan valid baik dari segi validitas isi maupun validitas konstruksi. Berdasarkan komentar dan saran dari validator, selanjutnya dilakukan perbaikan seperlunya. Di samping pendapat para ahli, instrumen ini juga diujicobakan pada 2 orang siswa kelas VIII untuk mengetahui apakah instrumen ini memenuhi kriteria uji keterbacaan.

2. Pedoman Wawancara.

Sebelum wawancara dilakukan, terlebih dahulu juga dilakukan validasi pedoman wawancara. Pedoman wawancara ini berisi garis besar pertanyaanpertanyaan yang ditanyakan kepada subjek wawancara pada saat wawancara berlangsung. Penyusunan pedoman wawancara ini bertujuan untuk mengungkap secara mendalam proses matematisasi horizontal dan vertical subjek dalam Tes Pemecahan Masalah (TPM).

\subsection{Teknik Pengumpulan Data}

Teknik pengumpulan data yang digunakan pada penelitian ini adalah metode wawancara berbasis tes. Hal ini bertujuan agar peneliti dapat melakukan wawancara secara langsung pada saat subjek mengerjakan Tes Pemecahan Masalah (TPM). 
Wawancara yang digunakan pada penelitian ini adalah wawancara tidak terstruktur.

\subsection{Prosedur Penelitian}

Secara garis besar prosedur yang dilakukan dalam penelitian ini adalah sebagai berikut.

1. Menyusun Instrumen.

Instrumen data yang disusun dalam penelitian ini terdiri dari Tes Pemecahan Masalah (TPM) dan pedoman wawancara.

2. Melakukan Validasi Instrumen.

Instrumen data yang divalidasi adalah Tes Pemecahan Masalah (TPM) dan pedoman wawancara. Masing-masing validator diberikan bentuk TPM, dan pedoman wawancara yang telah tersusun, serta lembar penilaian validasi.

3. Melakukan Observasi ke Sekolah (Lokasi Penelitian).

Observasi ke lokasi penelitian ini dilakukan untuk memperoleh informasi dari pihak sekolah, baik berupa perizinan penelitian, materi pembelajaran matematika, kelas yang akan dijadikan sebagai subjek penelitian, dan jadwal penelitian, serta mengenai kondisi lingkungan sekolah.

4. Memilih Subjek Penelitian.

Peneliti memilih tiga subjek berdasarkan hasil pengerjaan tes VHGT dan memperhatikan pertimbangan guru yang berkaitan dengan kemampuan komunikasi subjek untuk mengemukakan pendapat atau jalan pikirannya secara lisan maupun tulisan.

5. Melakukan Wawancara

Berbasis Tes.

Wawancara dilakukan kepada setiap subjek yang terpilih ketika mereka mengerjakan Tes Pemecahan Masalah (TPM). Wawancara tersebut dilakukan untuk mendapatkan gambaran tentang proses matematisasi horizontal dan vertical mereka.

6. Menganalisis Hasil TPM dan Wawancara.

Peneliti menganalisis jawaban tertulis dan hasil wawancara subjek yang terpilih melalui hasil TPM sesuai dengan tahapan pemecahan masalah menurut Polya. Analisis tersebut dilakukan untuk mendapatkan gambaran tentang proses berpikir lateral siswa dalam pemecahan masalah .

\section{HASIL DAN PEMBAHASAN}

\section{A. Pelaksanaan penelitian}

Langkah pertama yang dilakukan dalam melaksanakan penelitian yaitu melakukan pretest 1 untuk mengetahui kemampuan awal siswa dalam pemahaman geometri, mencari subjek dengan tes VGHT kemudian membuat instrumen penelitian yang terdiri dari soal tes kemampuan pemecahan masalah yang sesuai dengan indikator polya dan berpikir lateral, kunci jawaban soal tes pemecahan masalah yang sesuai dengan indikator polya dan berpikir lateral, pedoman penilaian kemampuan pemecahan masalah yang sesuai dengan indikator polya dan berpikir lateral dan pedoman wawancara. Pembuatan instrumen penelitian disesuaikan dengan indikator dan aspek kemampuan pemecahan masalah yang sesuai dengan indikator polya dan berpikir lateral. Selanjutnya dilakukan uji validitas terhadap instrumen penelitian. Instrumen penelitian tersebut diuji validitas isinya dan untuk pedoman wawancara diuji validitasnya mengenai kesesuaian antara pertanyaan wawancara, indikator, dan aspek pemecahan masalah yang sesuai 
dengan indikator polya dan berpikir lateral. Lembar validasi soal berupa kolom penilaian tentang kevalidan soal dan lembar validasi pedoman wawancara berupa tabel pemetaan antara indikator dan aspek pemecahan masalah yang sesuai dengan indikator polya dan berpikir lateral dengan nomor pertanyaan. Uji validitas terhadap instrumen penelitian dilakukan dengan cara memberikan instrumen penelitian kepada validator yang berasal dari pakar ahli geometri dan guru sekolah. Selain melakukan uji validitas, validator diminta untuk memberikan saran dalam memilih satu soal dari empat soal yang diberikan, soal tersebut akan digunakan sebagai soal tes, sedangkan untuk soal yang lain akan dijadikan sebagai soal tes.

\section{B. Analisis Data}

Pada subbab ini berturut-turut disajikan tentang pengelompokkan subjek yang sesuai dengan tahapan berpikir Van hiele yaitu tes VGHT dan hasil tes pemecahan masalah. Tes VHGT terdiri atas pertanyaan pilihan ganda (MCQs) dalam lima subtes. Setiap subtes terdiri atas 5 soal berdasarkan pada satu tingkat van Hiele. Sehingga terdapat 15 soal dalam tes untuk menentukan pencapaian peserta didik dari tingkat van Hiele 0,1, dan 2 pada penelitian ini. Setiap pertanyaan siswa menjawab yang benar sesuai dengan kemampuan tingkat berpikir geometri yang dimiliki. Pada test perkembangan berpikir geometri Van Hiele VHGT setiap level terdiri dari lima pertanyaan dengan kriteria dalam menentukan level berpikir geometri, yaitu (a) Jika siswa dapat menjawab 3-5 pertanyaan dengan benar pada level 0 maka siswa tersebut mencapai tingkat berpikir geometri level 0; b) jika siswa dapat menjawab 3-5 pertanyaan dengan benar pada level 1 maka siswa tersebut mencapai tingkat berpikir geometri level 1 danseterusnya; c) jika siswa tidak menjawab dengan benar 3 atau lebih pertanyaan pada level 2, 3 dan 4 , maka siswa tersebut mencapai tingkat berpikir geometri level 1.

Dari tes VGHT diperoleh terdapat 6 siswa berada pada level 0, 22 siswa berada pada level 1, 2 siswa berada pada level 2 . Dimana siswa mampu mengindentifikasi sifat sebuah bangun geometri dengan cara mengukur atau melipat namun tidak secara terperinci melakukan pengindentifikasian terhadap sifat-sifat bagun. Siswa juga dapat mengidentifikasi sifat yang sama dan berbeda dari dua buah bangun, namun tidak dapat melihat hubungan antara bangun tersebut. Selain itu siswa juga dapat menyelesaikan masalah geometri yang berkaitan dengan sifat-sifat bangun segi empat, namun sebagian besar siswa jarang sekali mengaplikasikan sifat-sifat dari bangun. Berdasarkan pertimbangan dari guru dan nilai ulangan harian berdasarkan indikator berpikir lateral maka dipilihlah 3 subjek yaitu 1 subjek untuk level 0 yang dikodekan (S1), 1 subjek untuk level 1 (S2), dan 1 subjek untuk level 2(S3).

Adapun hasil pengerjaaan 3 subjek dengan 2 soal antara lain
A. Siswa

$\begin{array}{llr}\text { lateral } \quad \text { Pertama } & \begin{array}{r}\text { dalam } \\ \text { Merencanakan }\end{array} \\ \text { Penyelesaian (Soal.1) } & \text { Cara }\end{array}$

Adapun hasil pengerjaan S1 untuk soal 1 adalah sebagai berikut

1. Memahami masalah

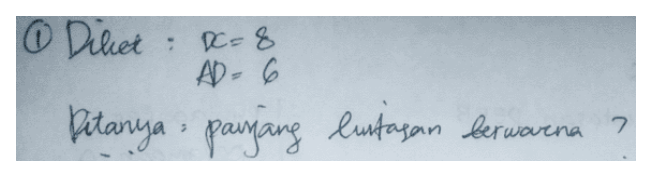

Gambar 1 S1 Memahami Masalah soal 
Terlihat pada gambar 1 tersebut bahwa SL1 dapat menetapkan apa yang diketahui dan apa yang ditanyakan pada soal tersebut. Hal ini menunjukkan bahwa S1 telah mampu menggunakan ide apa yang ada dalam soal 1 tersebut.

2. Merencanakan Penyelesaian Masalah

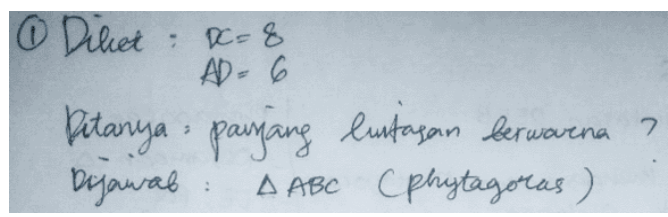

Gambar 2 S1 Merencanakan Penyelesaian Masalah

Terlihat pada gambar 2 siswa S1 dapat mengidentifikasi strategi-strategi pemecahan masalah yang sesuai untuk menyelesaikan masalah sebagai cara penyelesaian dalam memecahkan masalah pada soal. Tetapi S1 tidak membuat

$$
\begin{aligned}
\text { Dyawal : } & \triangle A B C \text { (phytagoras) } \\
& A C=\sqrt{8^{2}+5^{2}}=\sqrt{100}
\end{aligned}
$$

rencana penyelesaian yang benar dalam mengerjakan soal no 1. Hal ini menunjukkan bahwa S1 tidak mampu mencari cara lain dalam memandang permasalahan pada soal no 1 .

3. Melaksanakan

Rencana

Penyelesaian Masalah

Gambar 3 S1 Melaksanakan

Rencana Penyelesaian Masalah

Terlihat pada gambar 3 tersebut bahwa S1 menggunakan prosedur yang telah dilakukan pada langkah sebelumnya,untuk menentukan panjang lintasan berwarna dari bangun persegi panjang. Tetapi tidak menyelesaikan ke tahap terakhir yaitu sampai mencari segitiga $\mathrm{ABC}$. hal ini menunjukkan bahwa $\mathrm{S} 1$ hanya bisa menjalankan prosedur sebagian tetapi tidak bisa menemukan penyelesaian soal tersebut sehingga jawaban yang dikerjakan siswa no 1 salah.

4. Memeriksa Kembali Penyelesain Masalah

S1 tidak melakukan pengecekan kembali apakah yang dikejakannya sudah benar atau salah. Dikarenakan S1 tidak bisa mendapatkan hasil dari penyelesaian soal 1

\section{B. Siswa Kemampuan Berpikir lateral Kedua dalam Merencanakan Cara Penyelesaian (Soal.1) \\ Memahami masalah}

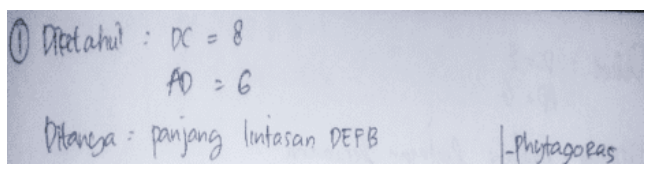

\section{Gambar 4 S2 Memahami Masalah soal} Terlihat pada gambar 4 tersebut bahwa S2 dapat menetapkan apa yang diketahui dan apa yang ditanyakan pada soal tersebut. Hal ini menunjukkan bahwa S2 telah mampu menggunakan ide apa yang ada dalam soal 1 tersebut.

1. Merencanakan Penyelesaian Masalah

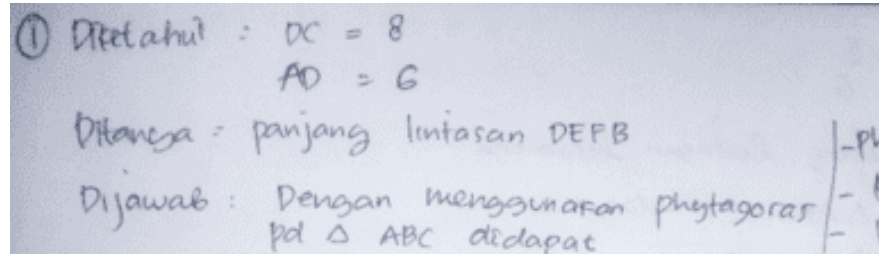

Gambar 5 S2 Merencanakan Penyelesaian Masalah

Terlihat pada gambar 5 tersebut bahwa S2 setelah mengetahui unsur-unsur yang 
diketahui dan ditanya dari soal 1 maka S2 membuat cara untuk menyelesaikan soal nomer 1 dengan menggunakan rumus phytagoras tetapi tidak rinci. Hal ini menunjukkan bahwa S2 mampu mencari cara lain dalam memandang permasalahan pada soal no 1 .

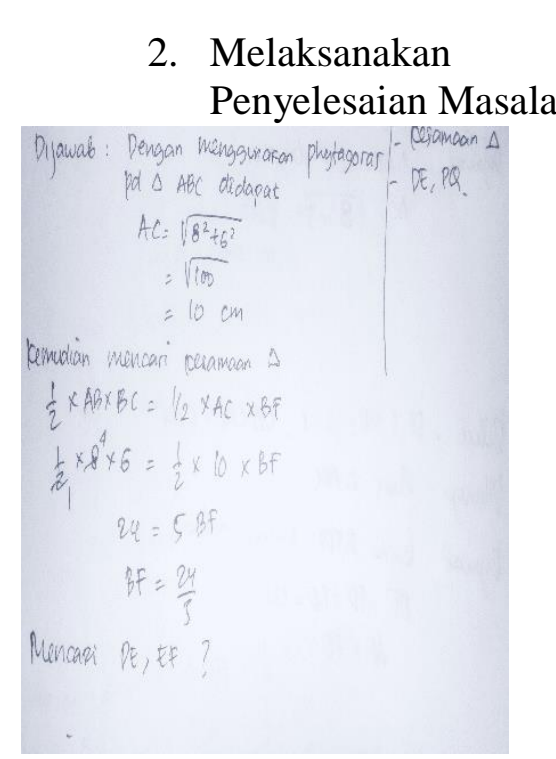

Gambar 6 S2 Melaksanakan Rencana Penyelesaian Masalah

Terlihat pada gambar 6 tersebut bahwa S2 menggunakan prosedur yang telah dilakukan pada langkah sebelumnya,untuk menentukan panjang lintasan berwarna dari bangun persegi panjang dengan mencari kesamaan dari segitiga ABC tetapi belum mencari panjang sisi yang lain. hal ini menunjukkan bahwa S2 telah menjalankan prosedur pada langkah sebelumnya dengan baik tetapi tidak bisa menemukan penyelesaian soal tersebut.

\section{Memeriksa Kembali Penyelesain Masalah}

S2 tidak melakukan pengecekan kembali apakah yang dikejakannya sudah benar atau salah.Dikarenakan S2 hanya mengerjakan sebagian penyelesaian dari soal 1 sehingga belum mendapatkan hasil dari penyelesaian soal 1 .

\section{Siswa Kemampuan Berpikir lateral Ketiga dalam Merencanakan Cara Penyelesaian (Soal.1)}

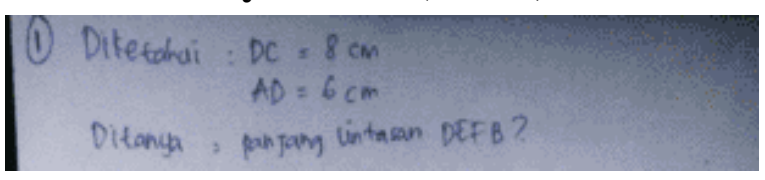

1. Memahami masalah

\section{Gambar 7 S3 Memahami Masalah soal}

Terlihat pada gambar 7 tersebut bahwa S3 dapat menetapkan apa yang diketahui dan apa yang ditanyakan pada soal tersebut. Hal ini menunjukkan bahwa S3 telah mampu menggunakan ide apa yang ada dalam soal 1 tersebut. 2. Merencanakan Penyelesaian

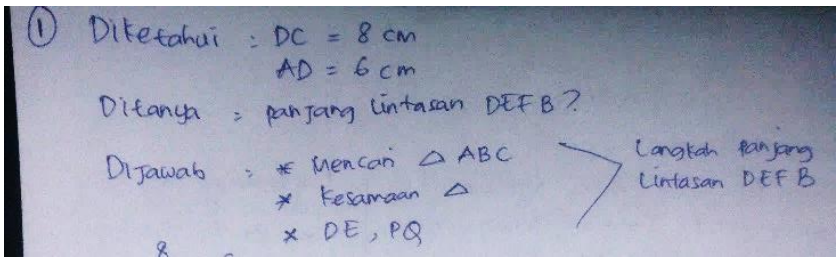

Masalah

Gambar 8 S3 Merencanakan

Penyelesaian Masalah

Terlihat pada gambar 8 tersebut bahwa S3 setelah mengetahui unsur-unsur yang diketahui dan ditanya dari soal 1 maka S3 membuat cara untuk menyelesaikan soal nomer 1 dengan menggunakan rumus phytagoras. Hal ini menunjukkan bahwa S3 mampu mencari cara lain dalam memandang permasalahan pada soal no 1 .

3. Melaksanakan Rencana Penyelesaian Masalah 
Gambar 9 S3 Melaksanakan Rencana Penyelesaian Masalah

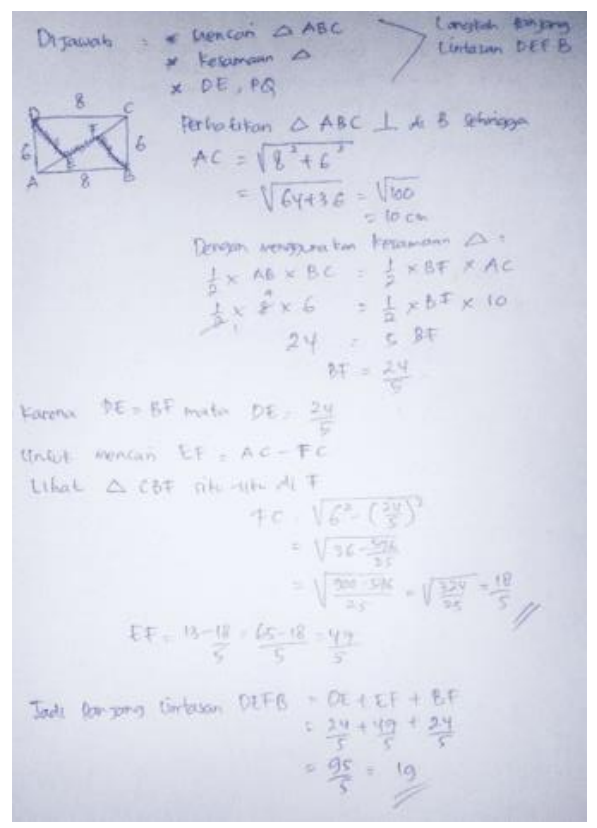

Terlihat pada gambar 9 tersebut bahwa S3 menggunakan prosedur yang telah dilakukan pada langkah sebelumnya,untuk menentukan panjang lintasan berwarna dari bangun persegi panjang yaitu mencari kesamaan dari segitiga $\mathrm{ABC}$ kemudian mencari panjang lintasan dari DEFB. hal ini menunjukkan bahwa S3 telah menjalankan prosedur pada langkah sebelumnya dengan baik dan melaksanakan rencana yang dinyatakan siswa pada soal 1 tersebut benar. Jadi dapat dikatakan bahwa S3 sudah mampu untuk melakukan rencana penyelesaian.

4. Memeriksa Kembali Penyelesaian Masalah

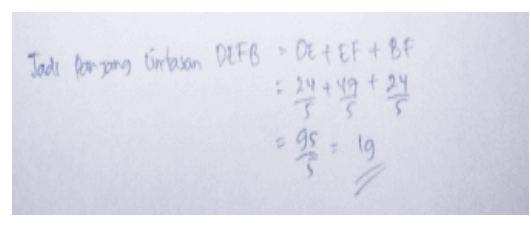

Gambar 10 S3 Memeriksa Kembali Penyelesaian Masalah
Terlihat pada gambar 10 tersebut bahwa S3 melakukan pengecekan kembali apakah yang dikerjakannya sudah benar atau salah dengan memberikan kesimpulan pada jawaban no.1.

\section{Siswa Kemampuan Berpikir lateral Pertama dalam Merencanakan Cara Penyelesaian (Soal.2)}

Adapun hasil pengerjaan S1 untuk soal 2 adalah sebagai berikut

1. Memahami masalah

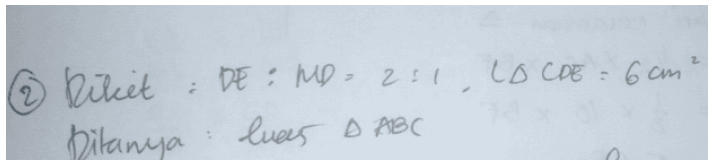

\section{Gambar 13 S1 Memahami Masalah soal}

Terlihat pada gambar 13 tersebut bahwa SL1 dapat menetapkan apa yang diketahui dan apa yang ditanyakan pada soal tersebut. Hal ini menunjukkan bahwa S1 telah mampu menggunakan ide apa yang ada dalam soal 1 tersebut.

2. Merencanakan Penyelesaian Masalah

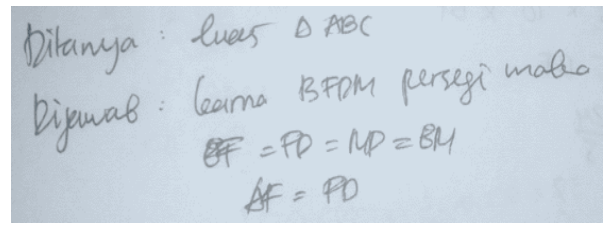

Gambar 14 S1 Merencanakan Penyelesaian Masalah

Terlihat pada gambar 14 siswa S1 dapat mengidentifikasi strategi-strategi pemecahan masalah yang sesuai untuk menyelesaikan masalah sebagai cara penyelesaian dalam memecahkan masalah pada soal. Tetapi S1 tidak membuat rencana penyelesaian yang benar dalam mengerjakan soal no 2. Hal ini 
menunjukkan bahwa S1 tidak mampu mencari cara lain dalam memandang permasalahan pada soal no 2 .

3. Melaksanakan Penyelesaian Masalah

Gambar 15 S1 Melaksanakan Rencana Penyelesaian Masalah Terlihat pada gambar 15 tersebut bahwa

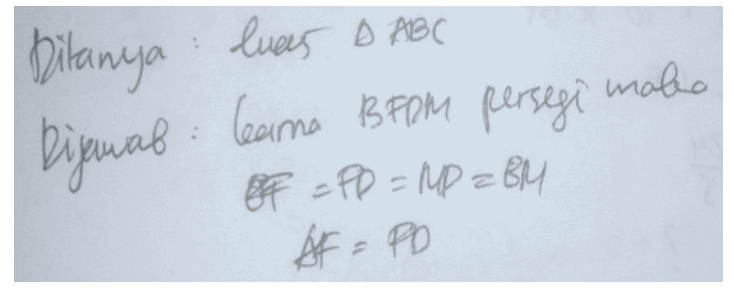

S1 menggunakan prosedur yang telah dilakukan pada langkah sebelumnya,untuk menentukan luas persegi BFDM. Tetapi tidak menyelesaikan ke tahap terakhir yaitu sampai mencari luas segitiga ABC. hal ini menunjukkan bahwa S1 hanya bisa menjalankan prosedur sebagian tetapi tidak bisa menemukan penyelesaian soal tersebut sehingga jawaban yang dikerjakan siswa no 2 salah.

4. Memeriksa Kembali Penyelesain Masalah

S1 tidak melakukan pengecekan kembali apakah yang dikejakannya sudah benar atau salah. Dikarenakan S1 tidak bisa mendapatkan hasil dari penyelesaian soal 2

\section{E. Siswa Kemampuan Berpikir lateral Kedua dalam Merencanakan Cara Penyelesaian (Soal.2)}

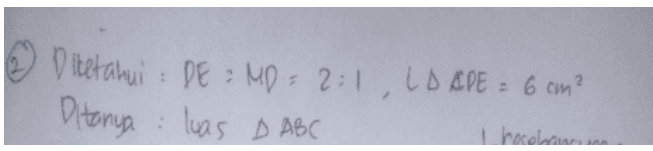

1. Memahami masalah

\section{Gambar 16 S2 Memahami Masalah} soal
Terlihat pada gambar 16 tersebut bahwa S2 dapat menetapkan apa yang diketahui dan apa yang ditanyakan pada soal tersebut. Hal ini menunjukkan bahwa S2 telah mampu menggunakan ide apa yang ada dalam soal 2 tersebut.

2. Merencanakan Penyelesaian Masalah

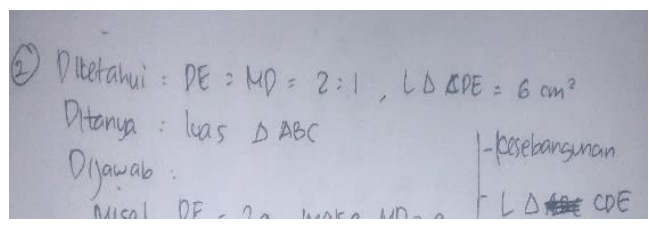

Gambar 17 S2 Merencanakan Penyelesaian Masalah

Terlihat pada gambar 17 tersebut bahwa S2 setelah mengetahui unsur-unsur yang diketahui dan ditanya dari soal 2 maka S2 membuat cara untuk menyelesaikan soal nomer 2 dengan menggunakan rumus phytagoras tetapi tidak rinci. Hal ini menunjukkan bahwa S2 mampu mencari cara lain dalam memandang permasalahan pada soal no 2.

3. Melaksanakan

Rencana Penyelesaian Masalah

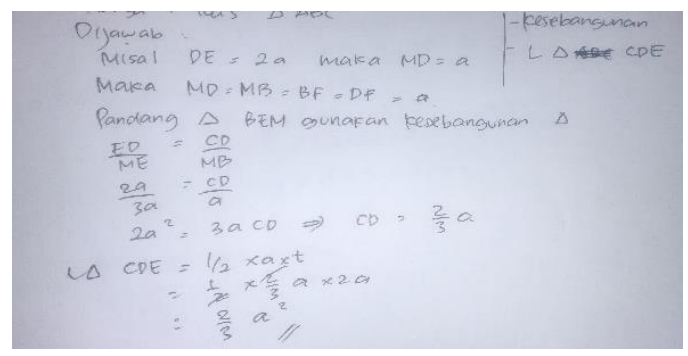

Gambar 18 S2 Melaksanakan Rencana Penyelesaian Masalah

Terlihat pada gambar 18 tersebut bahwa S2 menggunakan prosedur yang telah dilakukan pada langkah sebelumnya,untuk menentukan kesebangunan segitiga dan mencari luas segitiga CDE tetapi tidak 
mencari langkah terakhir yaitu segitiga ABC. hal ini menunjukkan bahwa S2 telah menjalankan prosedur pada langkah sebelumnya dengan baik tetapi tidak bisa menemukan penyelesaian soal tersebut.

4. Memeriksa Kembali Penyelesain Masalah

S2 tidak melakukan pengecekan kembali apakah yang dikejakannya sudah benar atau salah.Dikarenakan S2 hanya mengerjakan sebagian penyelesaian dari soal 2 sehingga belum mendapatkan hasil dari penyelesaian soal 2 .

\section{F. Siswa Kemampuan Berpikir lateral Ketiga dalam Merencanakan Cara Penyelesaian (Soal.2)}

1. Memahami masalah

\section{Gambar 19 S3 Memahami Masalah} soal

Terlihat pada gambar 19 tersebut bahwa S3 dapat menetapkan apa yang diketahui dan apa yang ditanyakan pada soal tersebut. Hal ini menunjukkan bahwa S3 telah mampu menggunakan ide apa yang ada dalam soal 2 tersebut.

2. Merencanakan Penyelesaian Masalah

Gambar 20 S3 Merencanakan

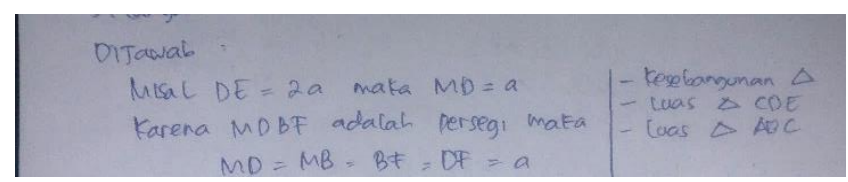

Penyelesaian Masalah
Terlihat pada gambar 20 tersebut bahwa S3 setelah mengetahui unsur-unsur yang diketahui dan ditanya dari soal 2 maka S3 membuat cara untuk menyelesaikan soal nomer 2 dengan menggunakan kesebangunan dan luas segitiga. Hal ini menunjukkan bahwa S3 mampu mencari cara lain dalam memandang permasalahan pada soal no 2 .

3. Melaksanakan Rencana Penyelesaian Masalah

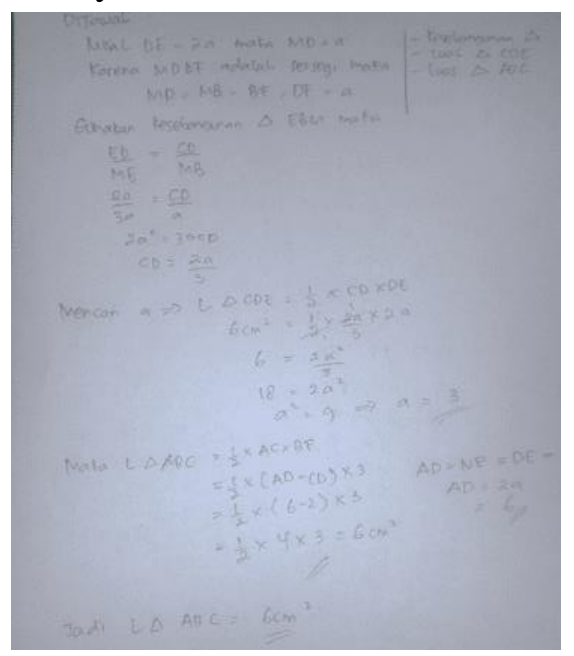

Gambar 21 S3 Melaksanakan Rencana Penyelesaian Masalah

Terlihat pada gambar 21 tersebut bahwa S3 menggunakan prosedur yang telah dilakukan pada langkah sebelumnya,yaitu mencari kesebangunan dari segitiga EBM kemudian mencari luas segitiga $\mathrm{CDE}$ kemudian mencari luas segitiga ABC. Hal ini menunjukkan bahwa S3 telah menjalankan

dengan baik dan melaksanakan rencana yang dinyatakan siswa pada soal no. 2 tersebut benar.

4. Memeriksa

Kembali

Penyelesaian Masalah 
Terlihat pada gambar 21 tersebut bahwa S3 melakukan pengecekan kembali apakah yang dikerjakannya sudah benar atau salah dengan memberikan kesimpulan pada jawaban no. 2

\section{SIMPULAN}

Pada siswa SMP level 0, Mereka mampu memahami soal, tidak mampu merencanakan masalah dengan benar, Tidak dapat menyelesaikan permasalahan dengan baik dan tidak memeriksa ulang pekerjaan dikarenakan tidak menemukan solusi penyelesaian. Pada siswa SMP level 1, mereka mampu memahami soal, mampu merencanakan masalah tetapi tidak rinci,mampu menyelesaikan permasalahan dengan baik tetapi tidak sampai selesai dan tidak memeriksa ulang pekerjaan dikarenakan tidak sampai menemukan solusi yang benar selanjutnya pada siswa SMP level 2, Mereka mampu memahami soal, mampu merencanakan masalah dengan benar, mampu menyelesaikan permasalahan dengan baik dan memeriksa ulang pekerjaan dikarenakan tidak menemukan solusi penyelesaian

\section{DAFTAR PUSTAKA}

Arikunto, S. (2011). Dasar - Dasar Evaluasi Pendidikan (Edisi Revisi). Jakarta: PT BumiAksara.

Budiarto, Mega Teguh. (2006). Bentuk Kesalahan dalam Menyelesaikan Permasalahn Geometri. Universitas Negeri Yogyakarta.

Chapman, D. (2011). Lateral thinking. www.odu.edu/.../Debono_Rep_Chapm an.pdf. Online. International Journal.

Clements, D.H \& Batitista. 1992. Geometry and Spatial Reasioning.
Dalam D.A. Grows, (ed.) Handbook of Research on Teaching and Learning Matematics. (pp.420-464). Newyork: MacMillan Publisher Company.

Cooney, T.J., Davis, E.J., Henderson, K.B.(1975). Dynamics of Teaching Secondary School Mathematics. Boston: Houghton Mifflin Company.

De Bono, Edward.(1990). Lateral Thinking.http://kioulanis.gr/rivips/imag es/Lateral_thinking.pdf. Online Book

De Bono, Edward.(1991). Berpikir Lateral Buku Teks Kreativitas. Jakarta : Erlangga.

De Bono, Edward. (1992). Mengajar Berpikir. Terjemahan Soemarjo. Jakarta : Erlangga.

De Bono, Edward. (2009). Think! Before it's too Late. London : Vermilion.

Nurani, Irawan, Sa'dijah. (2016). Level Berpikir Geometri Van Hiele Berdasarkan Gender Pada Siswa Kelas VII SMP Islam Hasanuddin Dau Malang. Jurnal Pendidikan, Volume: 1 Nomor: 5 Bulan Mei Tahun 2016 Halaman: 978-983. 